\title{
AKTIVITAS ANTIBAKTERI DAN ANTIBIOFILM NANOKOMPOSIT SENG OKSIDA-PERAK (ZnO-Ag) DENGAN MINYAK CENGKEH TERHADAP Pseudomonas aeruginosa
}

\section{The Activities of Antibacteria and Antibiofilm Zinc Oxide-Silver (ZnO-Ag) Nanocomposite with Clove Oil against Pseudomonas aeruginosa}

\author{
Yulianto Ade Prasetya ${ }^{1 *}$, Khoirun Nisyak ${ }^{2}$, A'yunil Hisbiyah ${ }^{2}$ \\ ${ }^{1}$ Laboratorium Mikrobiologi dan Bioteknologi, STIKES Rumah Sakit Anwar Medika Sidoarjo, Jalan Raya \\ By Pass Krian Km. 33 Sidoarjo, Jawa Timur 61253 \\ ${ }^{2}$ Laboratorium Kimia Organik, STIKES Rumah Sakit Anwar Medika Sidoarjo, Jalan Raya By Pass Krian \\ Km. 33 Sidoarjo, Jawa Timur 61253 \\ *Email: yuliantoadeprasetya@gmail.com
}

\begin{abstract}
Pseudomonas aeruginosa is a Gram-negative bacterium that often causes nosocomial infection because of its ability to produce biofilms so that it is resistant to various antibiotics. This research aims to determine the activity of zinc oxide-silver nanocomposites ( $\mathrm{ZnO}-\mathrm{Ag})$ with clove oil against P. aerugoinosa bacteria. ZnO-Ag nanocomposites were made using the Green One Pot Synthesis technique using a sonicator and microwave instruments. The nanocomposites formed were characterized by X-Ray Diffraction (XRD) to determine crystallinity and particle size and Scanning Electron Microscopy-Energy Dispersive X-Ray (SEM-EDX) to determine morphology and elements. The antibacterial activity and antibiofilm tests were carried out using the well diffusion and the microplate techniques, respectively. The resulted $\mathrm{ZnO}-\mathrm{Ag}$ nanocomposite formed had a size of $19.66 \mathrm{~nm}$, where $\mathrm{Ag}(47 \%)$ was of round shape, while $\mathrm{Zn}(35 \%)$ and $\mathrm{O}(18 \%)$ were fibrous. The ZnO-Ag had an inhibition zone of $14.9 \mathrm{~mm}$ against $\mathrm{P}$. aeruginosa and was able to prevent the attachment of the bacterial biofilm for 48 hours with 76,59\% inhibition percentage.
\end{abstract}

Keywords: antibacteria, antibiofilm, eugenol, Pseudomonas aeruginosa, nanotechnology

\begin{abstract}
ABSTRAK
Pseudomonas aeruginosa merupakan bakteri Gram negatif yang sering menyebabkan infeksi noskomial karena kemampuannya menghasilkan biofilm sehingga resisten terhadap berbagai antibiotik. Penelitian ini bertujuan untuk mengetahui aktivitas nanokomposit seng oksida-perak (ZnO-Ag) dengan minyak cengkeh terhadap P. aeruginosa. Nanokomposit ZnO-Ag dibuat dengan teknik Green One Pot Synthesis menggunakan instrumen sonikator dan gelombang mikro. Nanokomposit yang terbentuk dikarakterisasi menggunakan X-Ray Diffraction (XRD) untuk mengetahui kristalinitas dan ukuran partikel, Scanning Electron Microscopy-Energy Dispersive $X$ Ray (SEM-EDX) untuk mengetahui morfologi dan unsur yang terbentuk. Uji aktivitas antibakteri dilakukan dengan metode difusi sumuran dan uji antibiofilm dilakukan dengan teknik microplate. Hasil nanokomposit ZnO-Ag yang terbentuk memiliki ukuran sebesar 19,66 nm, dimana Ag (47\%) berbentuk bulat sedangkan $\mathrm{Zn}(35 \%)$ dan O (18\%) berbentuk fiber. Nanokomposit ZnO-Ag memunculkan zona hambat $14,9 \mathrm{~mm}$ terhadap $P$. aeruginosa dan mampu mencegah penempelan biofilm yang dihasilkan bakteri tersebut selama 48 jam dengan penghambatan $76,59 \%$.
\end{abstract}

Kata Kunci: antibakteri, antibiofilm, eugenol, Pseudomonas aeruginosa, nanoteknologi 


\section{PENDAHULUAN}

Pseudomonas aeruginosa termasuk bakteri Gram negatif, berbentuk batang, menghasilkan enzim oksidase dan katalase, mampu memproduksi pigmen serta termasuk $\beta$-hemolysis (Carroll et al. 2017). Bakteri ini tergolong patogen opportunistic yang sering menyebabkan infeksi pada pasien immunocompromised dan dikaitkan dengan penggunaan peralatan medis seperti kateter, stetoskop, dan defibelator (Long et al. 2018). Sebanyak 613 sampel strain $P$. aeruginosa yang berasal dari rumah sakit di India berhasil teridentifikasi dengan persentase tertinggi sebesar 28,35\% ditemukan di Unit Gawat Darurat (UGD), dan diikuti dengan 26,86\% Intensive Mediatory Care Unit (IMCU) 26,86\%, dan Neonatal Intensive Care Unite (NICU) $16,41 \%$ dan sisanya $14,92 \%$ ditemukan di ruang pediatrik dan $13,43 \%$ di ruang jantung (Pal et al. 2010). Bakteri ini menjadi sangat susah untuk diobati karena kemampuannya menghasilkan enzim beta laktamase dan biofilm (Ding et al. 2016). Resistensi pada bakteri ini dibagi dalam tiga tipe, antara lain: multidrug resistance (MDR), extensive drug resistance (XDR), dan pandrug resistance (PDR). Bakteri MDR memiliki sedikitnya resisten terhadap satu agen dalam tiga atau lebih kategori antimikroba. XDR didefinisikan sebagai bakteri resisten terhadap satu agen pada semua antimikroba kecuali dua atau lebih kategori, sedangkan bakteri dikatakan PDR jika resisten terhadap semua agen pada semua kategori antimikroba (Gill et al. 2016). Prevalensi $P$. aeruginosa di Iran pada kategori MDR dan XDR masing-masing sebesar $54,5 \%$ dan 33\% (Saderi dan Owlia, 2015) sedangkan pada PDR sebesar $76 \%$ dari 38 isolat yang berasal dari rumah sakit pada pasien dengan luka terbuka (El-Shouny et al. 2018). Biofilm yang dihasilkan oleh bakteri ini juga bertanggungjawab terhadap prevalensi tersebut yang didefinisikan sebagai sekumpulan koloni bakteri yang menempel pada bahan netral seperti logam berat, permukaan mineral, bahkan pada jaringan tubuh manusia dengan mensekresikan extracellular polymeric substance (EPS) (Goncalves et al. 2014). Hampir 80\% infeksi disebabkan oleh bakteri pembentuk biofilm yang mampu hidup pada kondisi lingkungan kekurangan nutrisi, perubahan $\mathrm{pH}$ esktrim, mampu menghindari fagositosis, dan mampu mentoleransi sejumlah antimikroba (Hall dan Mah 2017). Walaupun beberapa peralatan medis sudah dilapisi perak (Ag) namun infeksi nosokomial masih tinggi, sehingga diperlukan pengembangan bahan antibakteri dan antibiofilm dengan memanfaatkan nanoteknologi, salah satunya nanokomposit.

Nanokomposit didefinisikan sebagai penggabungan antara dua material atau lebih dengan ukuran kurang dari $100 \mathrm{~nm}$ yang memiliki beberapa keunggulan berupa luas permukaan yang tinggi, reaktivitas yang spesifik, dan mampu meningkatkan penghantaran obat (Ahmed et al. 2020). Nanokomposit dapat dibuat dari dua material yang memiliki sifat sebagai antibakteri yaitu perak $(\mathrm{Ag})$ dan seng-oksida $(\mathrm{ZnO})$. Logam perak efektif melawan lebih dari 650 spesies bakteri patogen, sehingga bersifat spektrum luas (Dastjerdi dan Montazer 2010). Logam ini bekerja dengan cara menghambat sintesis sel bakteri sehingga metabolismenya menjadi terhambat. Perak dalam bentuk nanopartikel mampu menghambat bakteri $P$. aeruginosa pada konsentrasi $5 \mathrm{ppm}$ (Salomoni et al. 2017). Nanopartikel perak selain sebagai antibakteri juga dapat digunakan untuk obat antikanker, anti-inflamasi dan pengobatan luka (Ahmed et al. 2010). Seng oksida (ZnO) juga bersifat sebagai antibakteri dan antijamur dengan mekanisme kerja yaitu merusak dinding sel bakteri, menghambat sintesis sel, dan menganggu metabolisme sel. Seng oksida banyak digunakan dalam dunia medis karena komponennya yang unik, biokompatibel, dan toksisitasnya rendah. Seng oksida dalam bentuk nanopartikel mampu menghambat pertumbuhan bakteri Staphylococcus aureus (Musdalifa et al. 2019). Walaupun demikian, belum ada penelitian yang menggunakan $\mathrm{ZnO}$ dan $\mathrm{Ag}$ sebagai antibiofilm pada $P$. aeruginosa. Nanokomposit $\mathrm{ZnO}-\mathrm{Ag}$ dapat dibuat dengan menggunakan reduktor secara green synthesis. Metode green synthesis bersifat ramah lingkungan, ekonomis, sedikit menghasilkan produk buangan yang berbahaya dan menghasilkan hasil sintesis yang banyak. Green synthesis dibuat dengan memanfaatkan ekstrak tumbuhan sebagai bioreduktor yang banyak mengandung gugus hidroksil $(\mathrm{OH})$, karboksil $(-\mathrm{COOH})$, ikatan rangkap, dan kaya akan elektron (Hisbiyah et al. 2020). Salah satu bioreduktor yang 
berpotensi digunakan untuk green synthesis nanokomposit $\mathrm{ZnO}-\mathrm{Ag}$ adalah minyak cengkeh. Minyak cengkeh merupakan minyak atsiri khas Indonesia dan ditemukan berlimpah yang berasal dari tanaman Syzygium aromaticum. Minyak tersebut menjadi komoditas non-migas unggulan Indonesia, dengan genetik cengkeh yang besar dan sangat berharga untuk dikembangkan. Indonesia merupakan pemasok utama minyak cengkeh untuk pasar India dan Arab Saudi (Bustaman 2011). Kandungan minyak cengkeh yang utama merupakan eugenol (6068\%) dan memiliki aktivitas antioksidan (Perez-Roses et al. 2016). Eugenol merupakan senyawa golongan fenilpropanoid yang memiliki cincin aromatik, gugus metoksi $(-\mathrm{COOH})$, gugus hidroksil $(-\mathrm{OH})$, dan kaya akan ikatan rangkap (Hisbiyah et al. 2020) sehingga dapat digunakan sebagai bioreduktor pembentukan nanokomposit $\mathrm{ZnO}-\mathrm{Ag}$.

Penelitian ini menggunakan metode One Pot Green Synthesis untuk membuat nanokomposit seng oksida-perak ( $\mathrm{ZnO}-\mathrm{Ag}$ ). Tujuan dari penelitian ini adalah untuk mengetahui aktivitas nanokomposit seng oksida-perak (ZnO-Ag) dalam menghambat pertumbuhan bakteri dan biofilm yang dihasilkan $P$. aeruginosa. Penelitian tentang aplikasi nanokomposit $\mathrm{ZnO}-\mathrm{Ag}$ dengan minyak cengkeh untuk menghambat penempelan biofilm pada bakteri $P$. aeruginosa belum pernah dilakukan sebelumnya, sehingga diharapkan dapat digunakan sebagai kandididat bahan untuk peralatan medis dalam mencegah penyebaran infeksi nosokomial.

\section{BAHAN DAN METODE}

\section{Tempat dan waktu penelitian}

Penelitian dilakukan di Laboratorium Kimia Organik STIKES Rumah Sakit Anwar Medika untuk distilasi fraksinasi eugenol dari minyak cengkeh berdasarkan perbedaan titik didih. Selain itu juga dilakukan pembuatan nanokomposit seng oksida-perak ( $\mathrm{ZnO}-\mathrm{Ag}$ ) dengan minyak cengkeh menggunakan instrumen gelombang mikro (microwave termodifikasi) dan sonikator. Uji aktivitas antibakteri dan antibiofilm nanokomposit seng oksida-perak dilakukan di Laboratorium Mikrobiologi dan Bioteknologi STIKES Rumah Sakit Anwar Medika. Analisa kandungan eugenol pada minyak cengkeh dilakukan di
Laboratorium Kimia Organik Universitas Brawijaya Malang. Analisa nanokomposit ZnOAg dilakukan di Laboratorium Kimia Material Departemen Teknik Material Institut Teknologi Sepuluh Nopember (ITS) Surabaya, sedangkan analisa menggunakan Scanning Electron Microscope - Energy Dispersive XRay Spectroscopy (SEM-EDX) dilakukan di Laboratorium Energi dan Lingkungan ITS Surabaya. Waktu penelitian dilakukan selama enam (6) bulan dari bulan Juni hingga Nopember 2019.

\section{Alat dan bahan}

Bahan-bahan yang digunakan pada penelitian ini antara lain: perak nitrat (Merck), zink asetat dihidrat (Merck), minyak cengkeh (Dampit-Malang), akuades (Brataco Chemical), amonia (Merck), P. aeruginosa ATCC 27853 isolat dari Tropical Disease Diagnostic Center (TDDC) Universitas Airlangga, tryptic soy broth (Merck), ethanol (Merck), agar MuellerHinton (MHA, Merck), dimethylsulfoxide (DMSO, Merck) dan kristal violet (Merck). Peralatan utama yang diperlukan untuk penelitian adalah Ultrasonikator $(40 \mathrm{kHz} 120$ $\mathrm{W})$, microwave reactor (Electrolux), oven (DGG 9053 A), timbangan analitik (Ohaus px224/E), X-Ray Diffractometer (Panalytical X'Pert Pro), Scanning Electron MicroscopeEnergy Dispersive X-Ray Spectroscopy (SEM-EDX, Hitachi FLEXSEM 1000), microplate reader (Bio-Rad), dan Gas Chromatography-Mass Spectrophotometer (GCMS, Shimadzu QP 2010).

\section{Karakterisasi dan analisa minyak cengkeh}

Minyak cengkeh berasal dari tempat penyulingan di Jalan Hayam Wuruk 85, Dampit Malang (S 8० 10' 17.134", E 112 38' 20.958"), dan dianalisa kandungan eugenolnya menggunakan Gas ChromatographyMass Spectropotometry (GC-MS). Kadar eugenol ditingkatkan dengan melakukan destilasi fraksinasi dengan tekanan $40 \mathrm{mmHg}$ (Malahayati dan Rahmawati 2014). Pompa vakum pada tabung trap ditambahkan es dan garam dan dihubungkan dengan alat destilasi. Minyak cengkeh sebanyak $2 \mathrm{~L}$ dimasukkan ke dalam Labu ukur $5 \mathrm{~L}$ dalam heating mantle. Pemanasan dilakukan selama 3 jam dengan tekanan $10 \mathrm{mmHg}$. Uap minyak yang keluar pada kolom destilasi ditampung pada kondensor menjadi cairan. Pemurnian dilakukan dengan refluks pada 
rasio 40/4 yang berarti setiap 40 detik pertama katup magnetis mengatur pengeluaran kondensat tertutup dan kondesat dikembalikan ke kolom fraksinasi, pada saat tersebut akan terjadi proses pemisahan dan 4 detik berikutnya katup akan terbuka. Hasil fraksinasi kemudian dianalisa dengan GC-MS.

GC-MS terdiri dari fase diam dan fase gerak. Fase diam yang digunakan adalah Rxi-1MS (100\% dimetilpolisiloksan) dengan kolom yang memiliki panjang $30 \mathrm{~cm}$ dan diameter $0,25 \mathrm{~mm}$. Fase gerak berupa gas helium yang dikondisikan pada tekanan 37,1 $\mathrm{kPa}$ dan memiliki volume injeksi sebesar 5 $\mu \mathrm{L}$, suhu injektor $250{ }^{\circ} \mathrm{C}$, suhu sumber ion $230{ }^{\circ} \mathrm{C}$, suhu permukaan $230{ }^{\circ} \mathrm{C}$, dengan mode split 10 . Kolom diatur pada suhu $70{ }^{\circ} \mathrm{C}$ dan akan naik mencapai suhu $230^{\circ} \mathrm{C}$ dengan laju kenaikan $10^{\circ} \mathrm{C}$ per menit dan ditahan selama 3 menit dengan suhu akhir sebesar $270{ }^{\circ} \mathrm{C}$ (Suhendar dan Sogandi 2019).

\section{Sintesis nanokomposit}

Sintesis nanokomposit seng oksida perak ( $\mathrm{ZnO}-\mathrm{Ag})$ dengan minyak cengkeh dilakukan dengan teknik One Pot Green Synthesis menurut Pinjari et al. (2016) dan Azizi et al (2016) dengan kombinasi dan modifikasi. Minyak daun cengkeh sebanyak $15 \mathrm{~mL}$ ditambah dengan etanol $50 \mathrm{~mL}$ dalam Erlenmeyer $250 \mathrm{~mL}$. Campuran larutan tersebut dihomogenkan dengan Ultrasonikator selama 30 menit. Seng asetat dihidrat 3 $\times 10^{-3} \mathrm{M}$ sebanyak $100 \mathrm{~mL}$ ditambahkan secara perlahan-lahan dan sedikit demi sedikit pada campuran larutan sebelumnya. Amonia ditambahkan agar larutan mencapai $\mathrm{pH} 9$ dan dihomogenkan dengan ultrasonikator. Campuran larutan tersebut kemudian direaksikan pada microwave reactor $300 \mathrm{~W}$ dengan suhu $30{ }^{\circ} \mathrm{C}$ selama 30 menit. Sebanyak $100 \mathrm{~mL}$ perak nitrat $\left(\mathrm{AgNO}_{3}\right)$ ditambahkan pada microwave reactor sedikit demi sedikit. Variasi penambahan $\mathrm{AgNO}_{3}$ dilakukan pada waktu 10, 15, 20, 25, dan 30 menit. Campuran kemudian disaring dan dicuci dengan etanol murni hingga warna filtrat memudar. Nanokomposit $\mathrm{ZnO}-\mathrm{Ag}$ yang terbentuk kemudian dikeringkan pada suhu $130^{\circ} \mathrm{C}$ untuk selanjutnya dikarakterisasi.

\section{Karakterisasi nanokomposit}

Nanokomposit $\mathrm{ZnO}-\mathrm{Ag}$ yang terbentuk dikarakterisasi dengan $X$-Ray Diffractometer
(XRD) untuk mengetahui ukuran dan kristalinitas yang terbentuk. Nanokomposit $\mathrm{ZnO}-\mathrm{Ag}$ dimasukkan dalam plat aluminium berukuran $2 \times 2 \mathrm{~cm}$. Plat dialirkan sinar yang berasal dari radiasi $\operatorname{CuK}_{\alpha}(\lambda=1,54060 \AA)$. Data difraksi dilakukan pada rentang sudut $2 \theta$ dan kecepatan baca per detik. Sinar $X$ ditembakkan pada sampel nanokomposit ZnO-Ag sehingga detektor akan berputar dengan rentang sudut difraksi $2 \theta$, dan akan terbaca pada monitor berupa grafik difraktogram. Grafik difraktogram yang didapat kemudian dianalisa dengan Software Match versi 3.8.2 dan diterminasi dengan Origin Pro Software (Qais et al. 2019).

Karakterisasi morfologi dan komposisi nanokomposit ZnO-Ag dilakukan dengan Scanning Electron Microscope-Energy Dispersive X-Ray Spectroscopy (SEM-EDX). Nanokomposit ZnO-Ag dipotong dengan ukuran $2 \times 2 \mathrm{~cm}$ dengan diamond blade cutter tipe JMQ-12 pada kecepatan rendah. Permukaan sampel diamplas pada mesin poles MoPao 2D Grinder Polisher secara berturut-turut dari 120, 400, 800, 1200 hingga 2000. Terakhir sampel dipoles pada kain bludru dan diamond pasta 0,25 $\mu$ (Sujatno et al. 2015).

\section{Pembuatan kultur bakteri}

Sebanyak satu ose koloni bakteri $P$. aeruginosa ATCC 27853 diinokulasikan pada media tryptic soy broth (TSB) $100 \mathrm{~mL}$ dalam Erlenmeyer $250 \mathrm{~mL}$. Kultur diinkubasi pada suhu kamar dan digoyang pada rotatory shaker selama 24 jam. Sebanyak $1 \mathrm{~mL}$ kultur tersebut diinokulasikan pada media TSB 50 $\mathrm{mL}$ pada Erlenmeyer $100 \mathrm{~mL}$. Kultur diinkubasi selama 18 jam pada suhu kamar dan digoyang dengan rotatory shaker (Prasetya, 2017). Kultur ini kemudian dinamakan stok kultur untuk digunakan pada uji aktivitas antibakteri dan antibiofilm.

\section{Uji aktivitas antibakteri}

Nanokomposit ZnO-Ag berupa padatan dan dilarutkan dengan DMSO dengan konsentrasi antara lain 10, 15, 20, 25, 30, 35, 40, dan $45 \mu \mathrm{g} \mathrm{mL}^{-1}$. Bakteri $P$. aeruginosa diinokulasikan pada media $15 \mathrm{~mL}$ agar MuellerHinton cair pada tabung reaksi kemudian dituang pada cawan Petri steril. Kultur dibiarkan memadat 1-2 jam, dilubangi dengan cock borer, dan diberi nanokompsoit $\mathrm{ZnO}-\mathrm{Ag}$ sesuai dengan konsentrasi yang ditetapkan. Kultur selanjutnya diinkubasi pada suhu $37^{\circ} \mathrm{C}$ selama 
24 jam. Kontrol negatif yang digunakan adalah DMSO, sedangkan kontrol positif yang digunakan adalah meropenem $2 \mu \mathrm{g}$. Pengujian ini dilakukan sebanyak tiga kali ulangan.

\section{Uji antibiofilm}

Pembentukan biofilm oleh bakteri melalui beberapa mekanisme di antaranya penempelan atau adhesi sejumlah bakteri pada suatu bahan, kemudian sejumlah bakteri tersebut mulai mensekresikan extracellular polymeric substance (EPS), dan mulai terjadi ekspansi atau perluasan permukaan hingga terakhir mengalami maturasi atau matang (Walmiki dan Rai 2017). Pada tahap ini nanokomposit ZnO-Ag digunakan untuk mencegah penempalan dan sekresi EPS oleh $P$. aeruginosa. Konsentrasi nanokomposit ZnO-Ag untuk uji aktivitas antibiofilm yang digunakan sama seperti yang digunakan untuk uji antibakteri yakni 10, 15, 20, 25, 30, 35, 40, dan $45 \mu \mathrm{g} \mathrm{mL} \mathrm{mL}^{-1}$. Sebanyak $200 \mu \mathrm{L}$ seri konsentrasi nanokomposit $\mathrm{ZnO}-\mathrm{Ag}$ yang digunakan dimasukkan dalam microplate kemudian ditutup dan diinkubasi pada suhu 37 oC selama satu jam agar nanokomposit $\mathrm{ZnO}$ Ag menempel pada microplate. Isi microplate berupa nanokomposit ZnO-Ag dikeluarkan dan dimasukkan $200 \mu \mathrm{L}$ suspensi bakteri uji dari stok kultur dengan penambahan $200 \mu \mathrm{L}$ media tryptic soy broth (TSB). Kultur pada microplate ditutup dan diinkubasi pada suhu $37^{\circ} \mathrm{C}$ dengan rentang waktu 24, 48, 72 dan 96 jam. Kultur pada microplate dikeluarkan sesuai dengan waktu inkubasi yang ditentukan, kemudian dicuci dengan akuades sebanyak tiga kali. Sebanyak $200 \mu \mathrm{L}$ kristal violet $1 \%$ dimasukkan pada microplate dan diinkubasi selama 15 menit. Pewarna selanjutnya dibilas dengan akuades lagi sebanyak tiga kali dan tambahkan
$200 \mu \mathrm{L}$ etanol $70 \%$ dan diinkubasi selama 15 menit. Microplate diukur pada panjang gelombang $595 \mathrm{~nm}$ menggunakan microplate reader. Kontrol negatif yang digunakan adalah DMSO (Costa et al. 2016). Pengujian dilakukan sebanyak tiga ulangan dan dihitung dengan rumus menurut Costa et al. (2016), yaitu:

$\%$ Antibiofilm $=$

$$
\frac{(\text { OD kontrol negatif - OD sampel })}{\text { OD kontrol negatif }} \times 100 \%
$$

\section{HASIL DAN PEMBAHASAN}

\section{Hasil analisa GC-MS pada minyak cengkeh}

Berdasarkan hasil analisa minyak cengkeh menggunakan GC-MS (Tabel 1) diperoleh kadar eugenol sebesar 48,72\% (Gambar 1). Kadar ini perlu ditingkatkan kemurniannya dengan melakukan proses destilasi fraksinasi pada tekanan $10 \mathrm{mmHg}$. Hasil distilasi fraksinasi yang kemudian dianalisa menggunakan GC-MS menunjukkan hasil singnifikan, dimana kadar

Tabel 1. Kandungan senyawa minyak cengkeh menggunakan GC-MS

\begin{tabular}{clc}
\hline No. & Nama Senyawa & Kadar $(\%)$ \\
\hline 1. & Eugenol & 48,72 \\
2. & Geamcrene D & 1,39 \\
3. & Trans-karyofilene & 30,7 \\
4. & Alpha-humulene & 12,43 \\
5. & Farnesene & 0,48 \\
6. & Cadinene & 0,46 \\
7. & Ledane & 1,42 \\
8. & Karyofilene oksida & 3,31 \\
9. & Dodekana & 0,57 \\
10. & Patchoulene & 0,5 \\
\hline
\end{tabular}

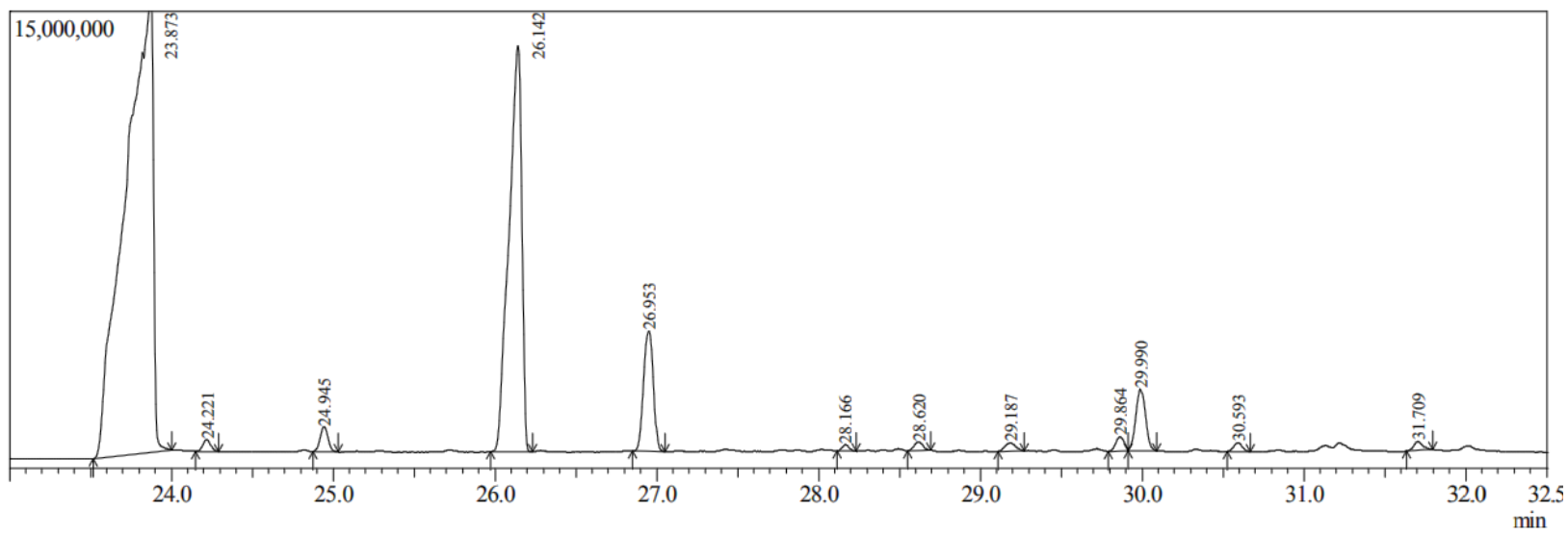

Gambar 1. Kromatogram minyak cengkeh, eugenol pada puncak I sebesar $48,1 \%$ dengan waktu retensi 23,873 
Tabel 2. Kandungan minyak cengkeh menggunakan GC-MS hasil destilasi fraksinasi

\begin{tabular}{llc}
\hline No. & Nama Senyawa & Kadar $(\%)$ \\
\hline 1. & Eugenol & 73 \\
2. & Trans-Karyofilene & 23,9 \\
3. & Alpha-Humulene & 3 \\
\hline
\end{tabular}

eugenol meningkat menjadi 73\% (Gambar 2) dengan dua kandungan lain yaitu transkaryofilene dan alpha-humulene (Tabel 2). Hal ini sesuai dengan penelitian Malahayati dan Rahmawati (2014), bahwa untuk meningkatkan kemurnian eugenol pada minyak cengkeh dan sesuai dengan standar United States Pharmacopeia (USP) yaitu sebesar $99,5 \%$ perlu dilakukan distilasi fraksinasi dengan tekanan terbaik sebesar $10 \mathrm{mmHg}$. Penelitian tersebut mendapatkan hasil yang sama berupa aroma khas cengkeh dan tidak berwarna. Tekanan pada destilasi fraksinasi sangat mempengaruhi kemurnian, rendemen, bobot jenis, indeks bias, dan putaran optik eugenol secara nyata. Ekstrak daun cengkeh bersifat antibakteri terhadap Escherichia coli dan Streptococcus aureus dengan kadar hambat minimal $10 \%$ (Ramadhani et al. 2020). Eugenol yang merupakan turunan senyawa fenol juga mampu menghambat bakteri $S$. mutans (Besra dan Kumar 2018) dan Porphyromonas gingivalis (Zhang et al. 2017) yang bekerja dengan cara merusak dinding sel bakteri, bertindak sebagai racun untuk protoplasma, dan menonaktfikan serta mendenaturasi protein yang berperan sebagai enzim pada bakteri (Bouarab-Chibane et al. 2019). Walaupun demikian, pada penelitian ini eugenol yang terkandung pada minyak cengkeh hanya berfungsi sebagai bioreduktor terhadap pembentukan nanokomposit ZnO-Ag. Pada tahap akhir, pembentukan nanokomposit $\mathrm{ZnO}-\mathrm{Ag}$ dicuci dengan etanol murni dan diuapkan pada suhu $130{ }^{\circ} \mathrm{C}$ untuk menghilangkan eugenol tersebut (Nisyak et al. 2020).

\section{Hasil analisa XRD pada nanokomposit}

Hasil nanokomposit ZnO-Ag (Gambar 3) selanjutnya dianalisa dengan X-Ray Diffractometer (XRD) (Gambar 4). Hasil

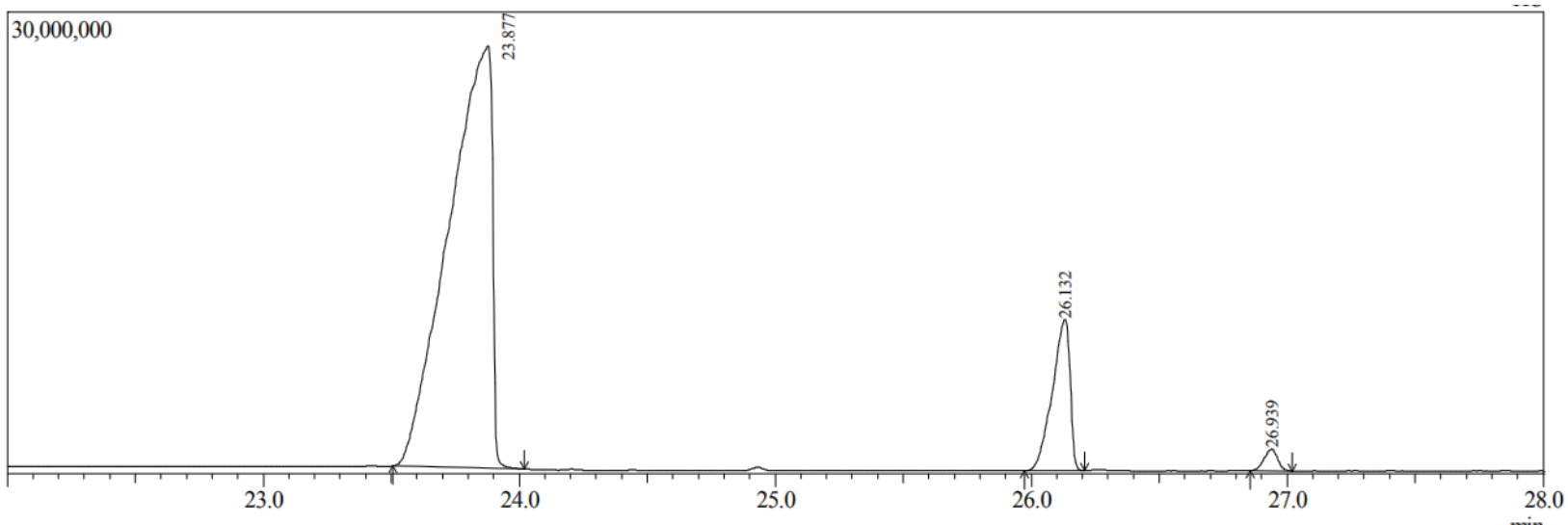

Gambar 2. Kromatogram distilat minyak cengkeh dengan kadar eugenol $73 \%$ dengan waktu retensi 23,387

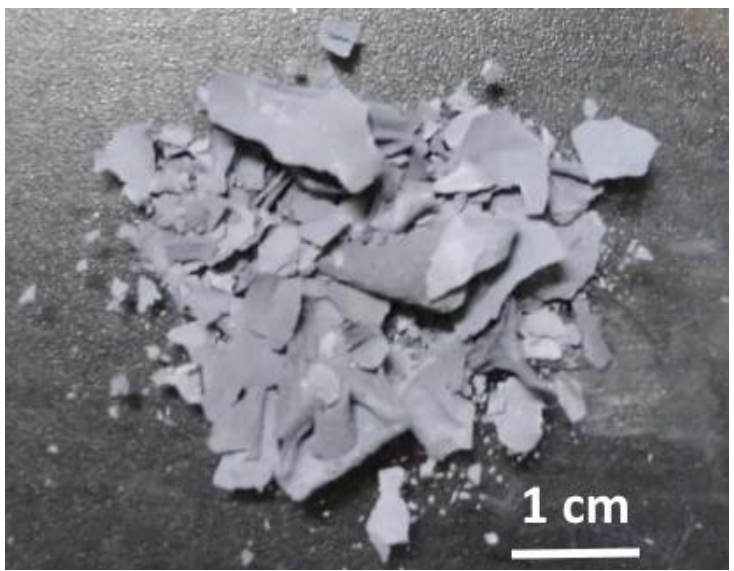

Gambar 3. Hasil nanokomposit $\mathrm{ZnO}-\mathrm{Ag}$ yang terbentuk secara kasat mata

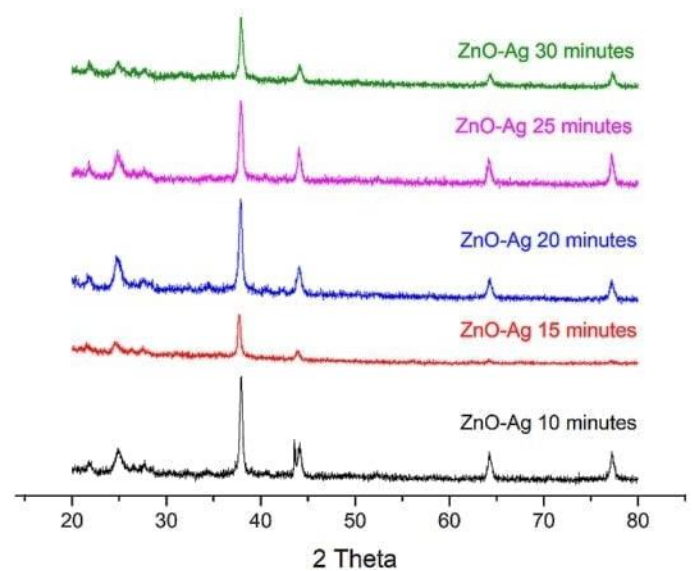

Gambar 4. Hasil analisa difraktogram $\mathrm{ZnO}-\mathrm{Ag}$ dengan minyak cengkeh 
tersebut menggambarkan bahwa pada sudut $2 \theta$ terdapat puncak sudut $38^{\circ}$ dan $44^{\circ}$ yang dapat dianalisa, dimana $\mathrm{Ag}$ teridentifikasi berbentuk bulat dan tidak terdapat perbedaan yang signifikan antara variasi waktu reaksi. Hasil difraktogram ini kemudian diidentifikasi dengan Software Match (Gambar 5), yang menunjukkan bahwa nanokomposit yang terbentuk memiliki lima bentuk diantaranya zink oksida, $\mathrm{ZnO}$ (zincite), $\mathrm{Zn}(\mathrm{OH})_{2}$ (Wülfingite), $\mathrm{Zn}(\mathrm{OH})_{2}$, dan $\mathrm{Ag}$. Dari gambar tersebut diketahui bahwa waktu reaksi selama 20 menit menunjukkan hasil yang terbaik dengan persentase $\mathrm{Ag}$ yang tinggi sebesar $67 \%$ dan tidak ada pengotor lain seperti $\mathrm{ZnO}$ (zincite) dan $\mathrm{Zn}(\mathrm{OH})_{2}$ (Wülfingite). Nanokomposit dengan $\mathrm{ZnO}$ yang tertinggi terdapat pada waktu reaksi 10 menit dengan presentase sebesar $44,7 \%$. Produk samping yang terbentuk pada sintesis nanokomposit $\mathrm{ZnO}-\mathrm{Ag}$ ini adalah $\mathrm{Zn}(\mathrm{OH})_{2}$ yang paling banyak ditemukan pada waktu reaksi selama 15 menit dan berbentuk trigonal serta $\mathrm{Zn}(\mathrm{OH})_{2}$ (Wülfingite) yang muncul pada waktu reaksi selama 25 menit. Untuk mengetahui rerata ukuran partikel pada nanokomposit $\mathrm{ZnO}-\mathrm{Ag}$ yang terbentuk dilakukan determinasi dengan persamaan Scherrer sedangkan persentase kristalinitas dikalkulasi dengan Origin Pro dan Microsoft Excel software. Hasil yang didapatkan bahwa semua variasi waktu reaksi sintesis nanokomposit $\mathrm{ZnO}-\mathrm{Ag}$ memenuhi kriteria dengan ukuran partikel kurang dari $100 \mathrm{~nm}$, dengan ukuran terkecil dan terbaik adalah $19,66 \mathrm{~nm}$ pada variasi waktu reaksi 20 menit (persentase kristalinitas 28\%) (Tabel 3). Oleh karena itu, nanokomposit $\mathrm{ZnO}-\mathrm{Ag}$ yang digunakan untuk uji aktivitas antibakteri dan antibiofilm adalah metode dengan waktu reaksi 20 menit. Mekanisme reaksi pembentukan $\mathrm{ZnO}-\mathrm{Ag}$ dengan minyak cengkeh terdapat pada Gambar 6.

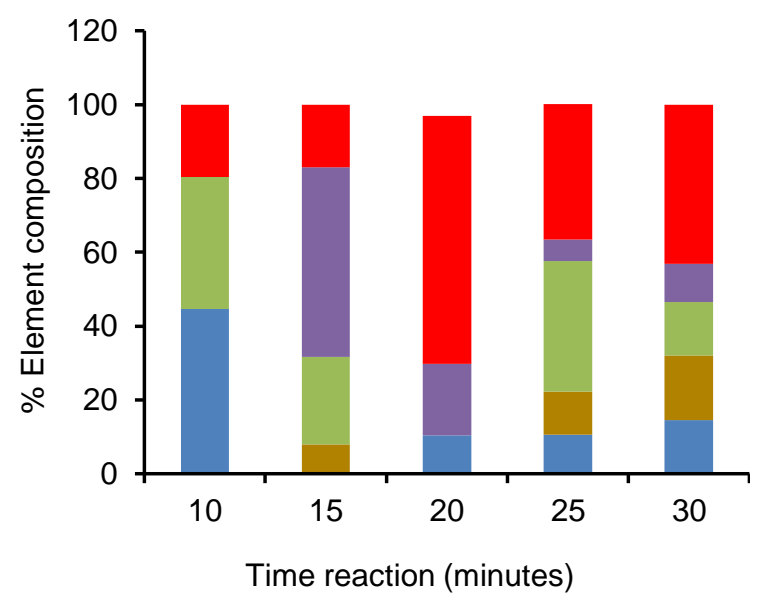

Gambar 5. Komposisi nanokomposit ZnO-Ag yang terbentuk dengan software match. ( $\square$ : Ag; ш: $\mathrm{Zn}(\mathrm{OH})_{2}$; : $\mathrm{Zn}(\mathrm{OH})_{2}$ (Wuelfingiete); ш: $\mathrm{ZnO}$ (Zincite); $: \mathrm{ZnO})$

Tabel 3. Rerata Ukuran partikel dan persentase kristalinitas nanokomposit $\mathrm{ZnO}-\mathrm{Ag}$

\begin{tabular}{ccc}
\hline $\begin{array}{c}\text { Variasi Reaksi } \\
\text { (menit) }\end{array}$ & $\begin{array}{c}\text { Rerata Ukuran } \\
\text { Partikel }(\mathrm{nm})\end{array}$ & $\begin{array}{c}\text { Kristalinitas } \\
(\%)\end{array}$ \\
\hline 10 & 36,44 & 23 \\
15 & 22,64 & 15 \\
20 & 19,66 & 28 \\
25 & 32,64 & 27 \\
30 & 28,29 & 20 \\
\hline
\end{tabular}<smiles>C=Cc1ccc(O[C@@H](O)O[C@H](O)Oc2ccc(C=C)cc2OC)c(OC)c1</smiles>

Gambar 6. Mekanisme reaksi nanokomposit $\mathrm{ZnO}-\mathrm{Ag}$ dengan minyak cengkeh 
Hasil analisa SEM-EDX pada nanokomposit Mekanisme sintesis nanokomposit $\mathrm{ZnO}-\mathrm{Ag}$ menggunakan minyak cengkeh yang memiliki kandungan utama berupa eugenol berfungsi untuk mereduksi ion $\mathrm{Ag}^{+}$menjadi $\mathrm{Ag}^{0}$, pembentukan nanopartikel $\mathrm{Ag}$, dan mengkomplekskan ion $\mathrm{Zn}^{2+}$ (Gambar 6). Hal ini dapat disebabkan karena adanya gugus fungsi hidroksil $(-\mathrm{OH})$, karbonil $(\mathrm{C}=\mathrm{O})$, dan ikatan rangkap (=) sebagai pereduksi ion logam, sehingga elektron dari cicin karbon tersebut mereduksi ion logam (Ghosh et al. 2015). Nanokomposit seng oksida-perak ( $\mathrm{ZnO}-\mathrm{Ag})$ dengan minyak cengkeh yang terbentuk, dimana analisa dengan XRD yang terbaik dilanjutkan dengan analisa morfologinya menggunakan instrumen Scanning Electron Microscopy-Energy Dispersive $X$-Ray (SEM-EDX). Hasil analisa nanokomposit $\mathrm{ZnO}-\mathrm{Ag}$ dengan variasi waktu 20 menit dengan SEM-EDX (Gambar 7) menunjukkan bahwa perak $(\mathrm{Ag})$ berbentuk bulat yang terdeposit ke dalam seng oksida ( $\mathrm{nO})$ yang berbentuk fiber. Pembentukan nanokomposit $\mathrm{ZnO}-\mathrm{Ag}$ dengan minyak cengkeh dapat tersusun dengan baik pada reaksi waktu 20 menit dapat dilihat melalui hasil XRD yang divisualisasikan dalam bentuk difraktogram (Gambar 4) dan dilanjutkan dengan analisa menggunakan software match (Gambar 6). Pada gambar difraktogram hasil analisa XRD menunjukkan bahwa sudut $2 \theta$ terdapat puncak sudut $38^{\circ}$ dan $44^{\circ}$ yang berarti terdapat adanya $\mathrm{Ag}$ dan ZnO. Kemudian adanya puncak tersebut dilanjutkan dengan identifikasi dengan software match yang menunjukkan lima komponen berbeda, dimana pada waktu reaksi 20 menit tidak ada komponen pengotor lain (hanya terdapat bentuk seng oksida, $\mathrm{Zn}(\mathrm{OH})_{2}$, dan $\left.\mathrm{Ag}\right)$. Hal ini diperkuat dengan adanya hasil dari SEM-EDX (Gambar 7) yang menunjukkan bahwa hanya terdapat unsur berupa Ag (47\%), Zn (35\%), dan O (18\%). Pada perbesaran $10.000 \times$ terlihat bentuk fiber yang ditutupi oleh bulatan kecil sehingga dapat dikatakan bahwa $\mathrm{ZnO}$ yang terbentuk tertutupi oleh bulatan $\mathrm{Ag}$. Dengan adanya
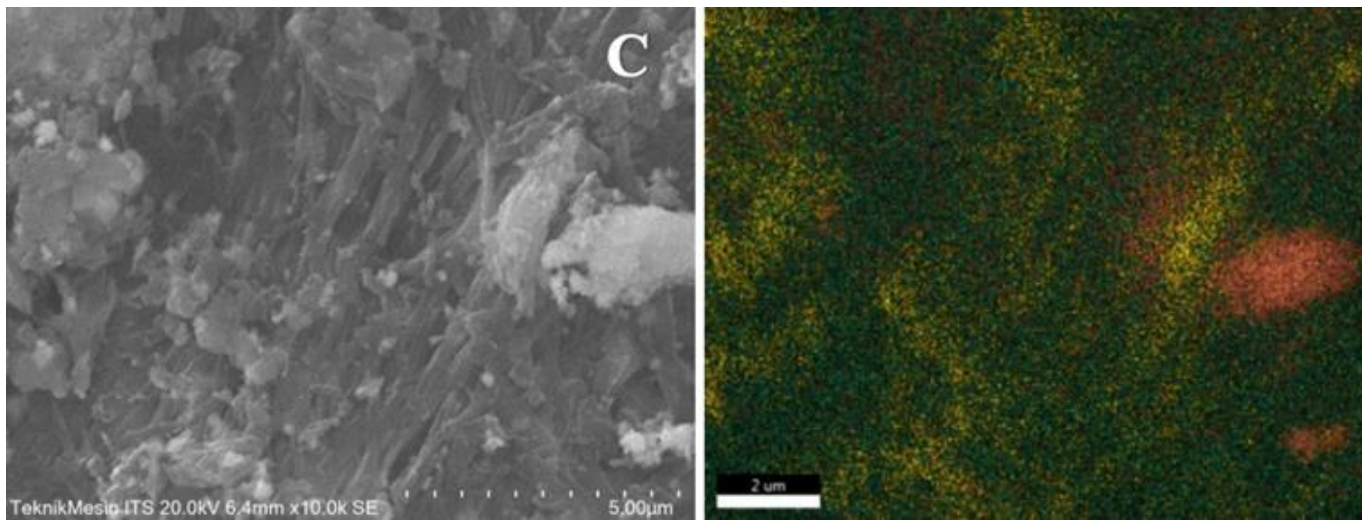

$18 \%$ O K

47\% AgL

35\% ZnK

Gambar 7. Hasil analisa SEM-EDX pada nanokomposit ZnO-Ag
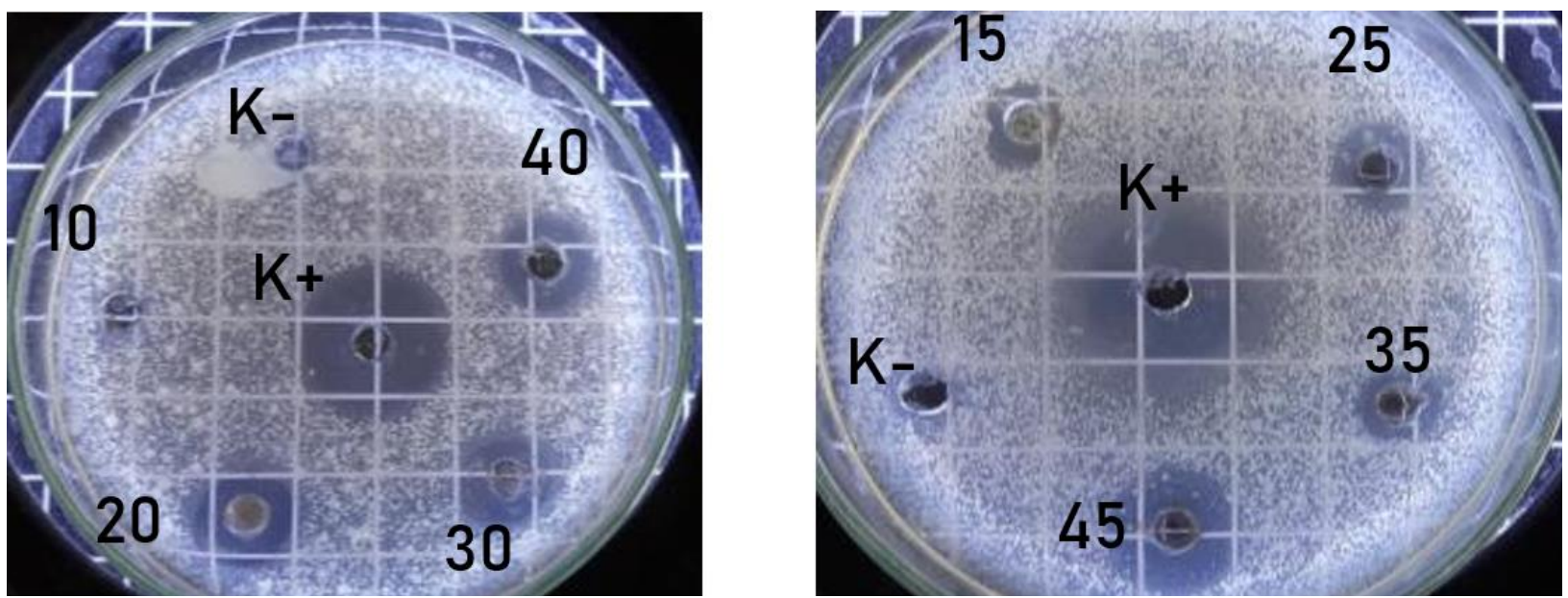

Gambar 8. Hasil uji aktivitas antibakteri nanokomposit $\mathrm{ZnO}-\mathrm{Ag}$ terhadap $P$. aeruginosa $(\mathrm{K}+$ : kontrol positif = meropenem $2 \mu \mathrm{g} \mathrm{mL}^{-1}$; K-: kontrol negatif = DMSO) 
doping $\mathrm{Ag}$ ini diperkirakan bahwa $\mathrm{Ag}$ menutupi $\mathrm{ZnO}$. Penelitian serupa dengan metode yang berbeda yakni dengan sol gel dan photochemical mampu mendeposisikan $\mathrm{Ag}$ yang berbentuk bulatan yang terdeposit pada ZnO yang berbentuk fiber (Habibi dan Sheibani 2013).

\section{Hasil uji aktivitas antibakteri}

Aktivitas antibakteri nanokomposit $\mathrm{ZnO}$-Ag dilakukan dengan metode cock-borer dimana nanokompsit $\mathrm{ZnO}-\mathrm{Ag}$ dibiarkan berdifusi pada media agar Mueller-Hinton. Nanokomposit $\mathrm{ZnO}-\mathrm{Ag}$ yang terbentuk sebelumnya berupa padatan sehingga harus dilarutkan dengan DMSO. DMSO merupakan pelarut polar aprotik golongan sulfosida yang bersifat netral, tidak bersifat bakterisidal, dan toksisitasnya rendah sehingga tidak akan mengurangi keefektivitasnya suatu obat (Assidqi et al. 2012). Berdasarkan hasil uji aktivitas antibakteri $\mathrm{ZnO}-\mathrm{Ag}$ terhadap bakteri $P$. aeruginosa (Gambar 8 ) bahwa konsentrasi $40 \mu \mathrm{g} \mathrm{mL} \mathrm{mL}^{-1}$ mampu menghambat pertumbuhan bakteri dengan zona hambat sebesar 14,99 mm dan pada konsentrasi 45 $\mu \mathrm{g} \mathrm{mL} \mathrm{m}^{-1}$ mencapai $16,20 \mathrm{~mm}$. Nanokompsoit $\mathrm{ZnO}-\mathrm{Ag}$ terbentuk dengan adanya bantuan minyak cengkeh sebagai bioreduktor. Walaupun minyak cengkeh berperan sebagai antibakteri, namun pada proses pembuatan minyak cengkeh dihilangkan dengan cara dicuci dengan etanol murni dan diuapkan pada suhu 130 ㅇ C sehingga dipastikan minyak atsiri tersebut hilang dan dibuktikan dengan tidak adanya unsur karbon pada hasil analisa SEM-EDX. Nanokomposit ZnO-Ag mampu menghambat pertumbuhan bakteri $S$. mutans penyebab karang gigi dengan mekanisme merusak membran sel, melepaskan ion $\mathrm{K}^{+}$, dan reaktif intraseluler oksigen dan lipid peroksidasi (Wang et al. 2017a). Seng oksida dalam bentuk nanopartikel memiliki aktivitas spektrum luas yaitu dapat menghambat pertumbuhan bakteri Campylobacter jejuni, Salmonella enterica serovar Enteritidis, dan E. coli O157:H7 (Xie et al. 2011). Perak dalam bentuk nanopartikel bekerja dengan cara menginduksi stres oksidasi, melepaskan ion metal, dan mekanisme non oksidatif (Wang et al. 2017b). Perlu studi lebih lanjut untuk mengetahui aktivitas nanokomposit $\mathrm{ZnO}-\mathrm{Ag}$ sebagai antibakteri, namun beberapa studi menduga bahwa mekanisme tersebut berhubungan dengan eksistensi gugus amino dan karboksil dari nanokomposit yang memiliki afinitas yang kuat terhadap dinding sel bakteri. Ukuran $\mathrm{Ag}$ dan $\mathrm{ZnO}$ yang berbentuk nano mengakibatkan luas permukaannya meningkat sehingga afinitas semakin tinggi untuk dapat masuk ke dalam sel bakteri. Nanokomposit $\mathrm{ZnO}-\mathrm{Ag}$ yang apabila telah masuk dalam sel bakteri mampu menghancurkan struktur heliks ganda DNA (Taha et al. 2020).

\section{Hasil uji aktivitas antibiofilm}

Uji aktivitas antibiofilm dilakukan dengan metode microplate 96 well yang selanjutnya dibaca menggunakan instrumen microplate reader pada panjang gelombang $595 \mathrm{~nm}$. Hasil uji aktivitas antibiofilm (Gambar 9) menunjukkan bahwa nanokomposit $\mathrm{ZnO}$ Ag mampu menghambat penempelan biofilm hingga waktu 72 jam dengan persentase penghambatan sebesar $76,59 \%$. Hasil ini lebih efektif dibandingkan dengan penelitian terdahulu, dimana konsentrasi nanopartikel $\mathrm{ZnO}$ sebesar $250 \mu \mathrm{g} \mathrm{mL}^{-1}$ mampu menghambat pembentukan biofilm pada $S$. aureus dan Proteus vulgaris (Mahamuni et al. 2019). Penelitian juga membandingkan aktivitas penghambatan biofilm terhadap nanopartikel $\mathrm{Ag}$ dan $\mathrm{ZnO}$ yang membuktikan bahwa nanokomposit $\mathrm{ZnO}-\mathrm{Ag}$ lebih efektif dalam menghambat pertumbuhan biofilm yang dihasilkan $P$. aeruginosa. Nanokomposit ZnO-Ag dapat digunakan sebagai kandidat bahan pelapis peralatan medis untuk mencegah infeksi nosokomial yang disebabkan oleh bakteri pembentuk biofilm. Mekanisme kerja penghambatan

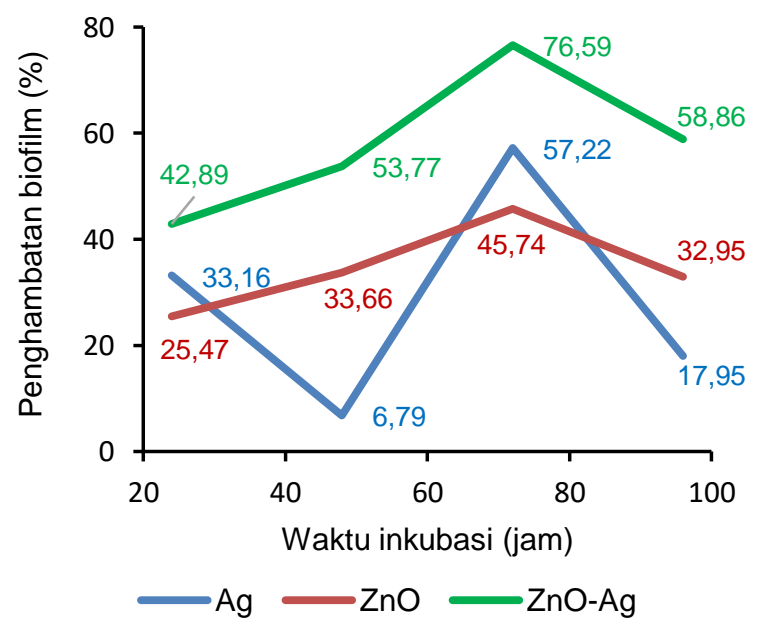

Gambar 9. Uji aktivitas antibiofilm nanokomposit $\mathrm{ZnO}$ Ag pada $P$. aeruginosa 
suatu senyawa terhadap biofilm terbagi menjadi tiga yang sesuai dengan pertumbuhan biofilm itu sendiri di antaranya mampu mencegah penempelan biofilm, mencegah maturasi biofilm, dan degradasi biofilm itu sendiri. Pada penelitian ini, nanokomposit $\mathrm{ZnO}-\mathrm{Ag}$ mampu mencegah penempelan biofilm $P$. aeruginosa selama 72 jam.

\section{KESIMPULAN}

Nanokomposit $\mathrm{ZnO}$-Ag dengan minyak cengkeh yang dibuat dengan metode Green One Pot Synthesis menghasilkan ukuran partikel sebesar 19,66 nm dengan persentase $\mathrm{Ag} 47 \%$ yang berbentuk bulat dan terdeposit pada $\mathrm{ZnO}$ yang berbentuk fiber ( $\mathrm{Zn}$ $35 \%$ dan $\mathrm{O}$ 18\%). Nanokomposit $\mathrm{ZnO}-\mathrm{Ag}$ mampu menghambat pertumbuhan bakteri $P$. aeruginosa dengan zona hambat mencapai $14,9 \mathrm{~mm}$ dan termasuk kategori aktif menghambat. Nanokomposit ZnO-Ag juga mampu mencegah penempelan biofilm yang dihasilkan $P$. aeruginosa hingga 72 jam dengan persentase penghambatan sebesar $76,59 \%$.

\section{UCAPAN TERIMAKASIH}

Penulis mengucapkan terima kasih kepada Kementrian Riset, Teknologi, dan Pendidikan Tinggi (Kemenristek-Dikti) yang telah mendanai penelitian ini pada skema Penelitian Kerjasama Perguruan Tinggi dengan nomer kontrak 113/ SP2H/ LT/ DRPM/ 2019.

\section{DAFTAR PUSTAKA}

Ahmed M, AI Sahli MS, Siddiqui MKJ (2010) Silver nanoparticle applications and human health. Clin Chim Acta 411: 1841-1848.

doi: 10.1016/j.cca.2010.08.016

Assidqi K, Tjahjaningsih W, Sigit S (2012) Potensi ekstrak daun patikan kebo (Euphorbia hirta) sebagai antibakteri terhadap Aeromonas hydrophila secara in vitro. $\mathrm{J}$ Mar Coast Sci 1: 113-124. Corpus ID: 83859722

Azizi S, Mohamad R, Abdul Rahim R, Moghaddam AB, Moniri M, Ariff A, Saad WZ, Namvab F (2016) ZnO-Ag core shell nanocomposite formed by green method using essential oil of wild ginger and their bactericidal and cytotoxic effects. Appl Surf Sci 384: 517-524. doi: 10.1016/j.apsusc.2016.05.052

Besra M, Kumar V (2018) In vitro investigation of antimicrobial activities of ethnomedicinal plants against dental carries pathogens. 3 Biotech 8: 257. doi: $10.1007 / \mathrm{s} 13205-018-1283-2$

Bouarab-Chibane $L$, Forquet $V$, Lanteri $P$, Clement Y, Leonard-Akkari L, Oulahal N, Degraeve P, Bordes C (2019) Antibacterial properties of polyphenols: Characterization and QSAR (Quantitative Structure-Activity Relationship) Models. Front Microbiol 10: 829. doi: 10.3389/fmicb.2019.00829

Bustaman S (2011) Potensi pengembangan minyak daun cengkeh sebagai komoditas ekspor Maluku. Jurnal Litbang Pertanian 30: 132-139. doi: 10.21082/jp3.v30n4.2011.p132-139

Carroll KC, Morse SA, Mietzner T, Miller S (2017) Jawetz, Melnick and Adelberg's Mikrobiologi Kedokteran. Edisi 27. Penerbit Buku Kedokteran, Jakarta

Costa GA, Rossatto FCP, Medeiros AW, Correa APF, Brandelli A, Frazzon APG, Da Motta ADS (2016) Evaluation antibacterial and antibiofilm activity of the antimicrobial peptide P34 against Staphylococcus aureus and Enterococcus faecalis. An Acad Bras Cienc 90: 73-85. doi: 10.1590/00013765201820160131

Dastjerdi R, Montazer M (2010) A review on the application of inorganic nanostructured materials in the modicication of textiles: focus on antimicrobial properties. Colloids Surf B Biointerfaces 79: 5-18. doi: 10.1016/j.colsurfb.2010.03.029

Ding C, Yang Z, Wang J, Liu X, Cao Y, Pan Y, Han L, Zhan S (2016) Prevalence of Pseudomonas aeruginosa and antimicrobial-resistant Pseduomonas aeruginosa in patients with pneumonia in mainlan China: a systematic review and meta-analysis. Int J Infect Dis 49: 119-128 doi: 10.1016/j.jid.2016.06.014

El-Shouny WA, Ali SS, Sun J, Samy SM, Ali A (2018) Drug resistance profile and molecular characterization of extended spectrum beta-lactamase (ES $\beta L$ )producing Pseudomonas aeruginosa 
isolated from burn wound infections. Essential oils and their potential for utilization. Microb Pathog 116: 301312. doi:10.1016/j.micpath.

2018.02.005

Ghosh T, Das AB, Jena B, Pradhan C (2015) Antimicrobial effect of silver zinc oxide $(\mathrm{Ag}-\mathrm{ZnO})$ nanocomposite particles. Front Life Sci 8: 47-54. doi: 10.1080/21553769.2014.952048

Gill JS, Arora S, Khanna SP, Kumar KH (2016) Prevalence of multidrugresistant, extensively drug-resistant, and pandrug-resistant Pseudomonas aeruginosa from a tertiary level intensive care unit. J Glob Infect Dis 8: 155-159. doi: 10.4103/0974777x.192962

Goncalves MDS, Delattre C, Balestrino D, Charbonnel N, Elboutachfaiti R, Wadouachi A, Badel S, Bernadi T, Michaud P, Forestier C (2014) Antibiofilm activity: A function of Klebsiella pneumonia capsular polysacharide. PLoS One 9: e99995. doi: 10.1371/journal.pone.0099995

Habibi MH, Sheibani R (2013) Nanostructure silver-doped zinc oxide film coating on glass prepared by sol-gel and photochemical deposition process: Application for removal of mercaptan. J Ind Eng Chem 19: 161-165. doi: 10.1016/j.jiec.2012.07.019

Hall CW, Mah T-F (2017) Molecular mechanisms of biofilm-based antibiotic resistance and tolerance in pathogenic bacteria. FEMS Microbiol Rev 41: 276 301. doi: $10.1093 /$ femsre/fux010

Hisbiyah A, Nisyak K, Prasetya YA, Iftitah ED, Srihardyastutie A (2020) Synthesis of $\mathrm{ZnO}-\mathrm{Ag}$ nanocomposites trough ultrasonication-microwave combination method with clove leaf oil. IOP Conf Series: Mater Sci Eng 833: 012070. doi: 10.1088/1757-899X/833/1/012070

Long SS, Prober CG, Fischer M (2018) Principles and Practice Pediatric Infectious Disease. Fifth Edition. Elseiver, Amsterdam. doi: 10.1016/C2013-0-19020-4

Mahamuni PP, Patil PM, Dhanavade MJ, Badiger MV, Shadija P G, Lokhande AC, Bohara RA (2019) Synthesis and characterization of zinc oxide nanoparticles by using polyol chemistry for their antimicrobial and antibiofilm activity. Biochem Biophys Rep 17: 7180. doi: 10.1016/j.bbrep.2018.11.007

Malahayati M, Rahmawati (2014) Optimasi tekanan dan rasio refluks pada destilasi fraksinasi vakum terhadap mutu eugenol dari minyak daun cengkeh (Eugenia caryophyllata). Konversi 3: 717. doi: $10.24853 /$ konversi.3.2.\%25p

Musdalifa K, Purnama MNK, Herawati (2019) Sintesis dan karakterisasi nanopartikel seng oksida $(\mathrm{ZnO})$ dan aplikasinya sebagain agen antibakteri Staphylococcus aureus pada kain katun jenis cotton combed. Indones $J$ Fundamen Sci 5: 15-25. doi: 10.26858/ijfs.v5i1.9372

Nisyak K, Prasetya YA, Hisbiyah A, Iftitah ED, Srihardyastutie A (2020) Synthesis of $\mathrm{ZnO}-\mathrm{Ag}$ with clove oil using ultrasonication method and its antibiofilm acticivity against Klebsiella pneumoniae. IOP Conf Ser: Mater Sci Eng 833: 012081. doi: 10.1088/1757899X/833/1/012081

Pal RB, Rodrigues M, Datta S (2010) Role of $P$ seudomonas in nosocomial infections and biological characterization of local strains. J Biosci Technol 1: 170-179

Perez-Roses R, Risco E, Vila R, Penalver P, Canigueral S (2016) Biological and nonbiological antioxidant activity of some essential oils. J Agric Food Chem 64: 4716-4724. doi: 10.1021/acs.jafc.6b00986

Pinjari DV, Pandit AB, Mhaske ST (2016) Ultrasound assisted green synthesis of zinck oxide nanorods at room temperature. Indian $\mathrm{J}$ Chem Technol 23: $221-226$

Prasetya YA (2017) Identifikasi gen CTX-M pada Escherichia coli penghasil extended spectrum beta lactamases (ESBLs) di RSUD Dr. Soetomo Surabaya. Jurnal Teknologi Laboratorium 6: 56-60. doi: 10.29238/ teknolabjournal.v6i2.92

Qais FA, Sahfiq A, Khan HM, Husain FM, Khan RA, Alenzai B, Alsalme A, Ahamd I (2019) Antibacterial effect of silver nanoparticles synthesized using Murraya koenigii (L.) against multidrugresistance pathogens. Bioinorganic Chem Appl 2019: 4649506. doi: $10.1155 / 2019 / 4649506$ 
Ramadhani A, Saadah S, Sogandi (2020) Efek antibakteri ekstrak daun cengkeh (Syzygium aromaticum) terhadap Escherichia coli dan Staphylococcus aureus. J Bioteknol Biosains Indones 7: 203-214. doi: 10.29122/ jbbi.v7i2.4146

Saderi H, Owlia P (2015) Detection of multidrug resistant (MDR) and extremely drug resistant (XDR) Pseudomonas aeruginosa isolated from patients in Tehran, Iran. Iran J Pathol 10: 265-271. doi: 10.7508/ijp.2015.04.003

Salomoni R, Leo P, Montemor AF, Rinaldi BG, Rodrigues MFA (2017) Antibacterial effect of silver nanoparticles in Pseudomonas aeruginosa. Nanotechnol Sci Appl 10: 115-121. doi: 10.2147/NSA.S133415

Suhendar U, Sogandi (2019) Identifikasi senyawa aktif ekstrak daun cengkeh (Syzygium aromaticum) sebagai inhibitor Streptococcus mutans. AlKauniyah J Biol 12: 229-239. doi: 10.15408/kauniyah.v12i2.12251

Sujatno A, Salam R, Bandriyana, Dimyati A (2015) Studi scanning electron microscopy (SEM) untuk karakterisasi proses oxidasi paduan zirkonium. J Forum Nuklir 9: 44-50. doi: 10.17146/jfn.2015.9.1.3356

Taha A, Ben Aissa M, Da'na E (2020) Green synthesis of an activated carbonsupported $\mathrm{Ag}$ and $\mathrm{ZnO}$ nanocomposite for photocatalytic degradation and its antibacterial activities. Molecules 25: 1586. doi: 10.3390/molecules25071586

Walmiki MR, Rai VR (2017) Cell attachment inhibition and anti-biofilm activity of Syzygium aromaticum, Cuminum cyminum and Piper nigrum essential oils against pathogenic bacteria. J Essential Oil Bearing Plants 20: 59-68. doi: 10.1080/0972060x.2017.1287011

Wang L, Hu C, Shao L (2017b) The antimicrobial activity of nanoparticle: Present situation and prospect for the future. Int J Nanomedicine 12: 12271249. doi: 2147/IJN.S121956

Wang S, Wu J, Yang H, Liu X, Huang Q, Lu Z (2017a) Antibacterial activity and mechanism of $\mathrm{Ag} / \mathrm{ZnO}$ nanocomposite against anaerobic oral pathogen Streptococcus mutans. J Mater Sci: Mater Med 28: 23. doi: 10.1007/s10856-016-5837-8

Xie Y, He Y, Irwin PL, Jin T, Shi X (2011) Antibacterial activity and mechanism of action of zinc oxide nanoparticle against Campylobacter jejuni. Appl Environ Microbiol 77: 2325-2331. doi: 10.1128/AEM.02149-10

Zhang Y, Wang Y, Zhu X, Cao P, Wei S, Lu Y (2017) Antibacterial and antibiofilm activities of eugenol from essential oil of Syzygium aromaticum (L) Merr \& LM Perry (clove) leaf against periodontal pathogen Porphyromonas gingivalis. Microb Pathog 113: 396-402. doi: 10.1016/j.micpath.2017.10.054 